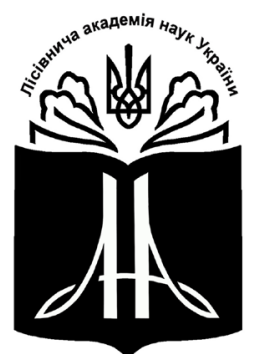

Forestry Academy of Sciences of Ukraine

Наукові праці Лісівничої академії наук України Proceedings of the Forestry Academy of Sciences of Ukraine

http://fasu.nltu.edu.ua https://doi.org/10.15421/411809

Article received 2018.03.01

Article accepted 2018.05.31
ISSN 1991-606X print

ISSN 2616-5015 online

(a) $\triangle$ Correspondence author

Yaroslav Fuchylo

fuchylo_yar@ukr.net

Clinicalstr., 25, Kyiv, 03141, Ukraine

УДК 630*2:630*17:582.475.2(292.485)

\title{
Ялина європейська у Правобережному Лісостепу України: перспективи використання та вдосконалення способів розмноження
}

\author{
Я.Д. Фучило', О.О. Середюк²
}

У Правобережному Лісостепу пристигаючі деревостани (вік 51-70 років) займають 43,5\% від загальної площі ялинників. Стиглі і перестійні насадження становлять понад 21,0\%, а молодняки - 13,9\%. Загалом насадження ялини європейської характеризуються високими лісівничо-таксаційними показниками. Частка участі ялини у складі штучних насаджень регіону досліджень з часом зменшується.

Дослідження клонової лісонасінної плантації ялини (свіжа діброва, $D_{2}$ ) показали, щуо найвищими показниками росту (I областей. Найнижчі показники росту відзначені у клонів прибалтійського походження.

Встановлено, що за рахунок використання стимуляторів росту і розвитку рослин можливе підвищення схожості насіння ялини європейської на 30,7\% і приживлюваності лісових культур - на 36,8\% порівняно 3 контролем.

Визначено оптимальні умови для ефективного клонального мікророзмноження рослин ялини європейської. Встановлено, щьо отримання 90\% асептичних здатних до регенерації мікропагонів забезпечує почергове витримування експлантів у 1\%-му розчині $\mathrm{AgNO}_{3}$ i 2,5\%-мy $\mathrm{NaClO}$. Використання безгормонального живильного середовища з половинною концентрачією Мурасіге-Скуга сприяє отриманню значної кількості рослинрегенерантів (90\%). Високу ефективність адаптації (95\%) отриманих рослин до умов іп vivo забезпечує субстрат, щя містить соснову кору, деревне вугілля, торф і сфагновий мох у пропориії 3:2:1:1.

Технологія вирошування садивного матеріалу ялини європейської із закритою кореневою системою передбачає використання слабокислих субстратів (рH 6,2), вирощування однорічних сіянців у мультиплатах, наступні два роки - у контейнерах місткістю 0,5 л та три роки - у трилітрових контейнерах.

Ключові слова: Picea abies (L.) Karst; деревостани; насіння; саджанці; стимулятори росту і розвитку рослин; контейнерна культура; мінеральні добрива; клональне мікророзмноження.

Вступ. Ялину європейську використовують в озелененні, декоративному садівництві та лісовому господарстві для створення насаджень різного цільового призначення. Зокрема, вже близько 300 років цей вид широко використовують у декоративному садівництві Європи. У нашій країні досвід культивування ялини сягає $150-200$ років - 3 часу створення таких визначних старовинних парків (на сьогодні - дендропарків) як «Краснокутський», «Олександрія», «Софіївка», «Тростянець», а також найстаріших ботанічних садів - Кременецького і Нікітського. За цей період узагальнено багатий досвід застосування хвойних порід i, зокрема, ялин у різних садово-паркових ландшафтах (лісопарки,

Фучило Ярослав Дмитрович - дійсний член Лісівничої академії наук України, доктор сільськогосподарських наук, професор, головний науковий співробітник. Інститут біоенергетичних культур і цукрових буряків НААН України, вул. Клінічна, 25, м. Київ, 03141, Україна. Тел. +38-067-605-91-41. E-mail: fuchylo_yar@ukr.net

2 Середюк Олександр Олексійович - кандидат сільськогосподарських наук, заступник директора ботанічного саду. Національний університет біоресурсів і природокористування України, вул. Героїв оборони, 15, м. Київ, 03041, Україна. Тел. +38-096-233-51-37. Е-mail: serediyk-olexandr@ukr.net 
парки, дендропарки, коніфератуми, присадибні ділянки тощо).

Створювати штучні лісові насадження 3 використанням ялини європейської на території Правобережного Лісостепу почали 3 кінця XIX століття. Ïї висаджували разом із дубом звичайним як швидкорослий деревний вид. Багато авторів вказували на високу продуктивність мішаних культур дуба та ялини (Holubets, 1958, Hordienko, 1967, Debryniuk, 2003), а також чистих ялинових деревостанів (Hordienko, 1953, Debryniuk, 2010, Kozlovsky, Kramarets \& Tselen, 2013, Fuchylo, 2011).

В умовах Правобережного Лісостепу України ялина європейська росте у монодомінантних і мішаних насадженнях, більшість яких (80\%) було створено у повоєнні 1945-1965 pp. (Vasilevsky, 2009). Вважалося, що такий захід у подальшому забезпечить отримання високопродуктивних, біологічно стійких деревостанів (Holubets, 1958). Проте з часом санітарний стан ялинників почав погіршуватися як в Україні (Bondar \& Hordienko, 2006, Vasilevsky, 2009, Debryniuk, 2011, Kozlovsky, Kramarets \& Tselen, 2013), так і за іiі межами (Zhigunov, Semakova \& Shabunin, 2007, Grodzki, 2007, Leontovyc \& Kunca, 2006).

Зважаючи на процеси деградації насаджень ялини європейської та важливе їі господарське і соціальне значення, особливої актуальності набувають дослідження стану, росту, розвитку та підвищення біологічної стійкості ялинників у різних грунтовокліматичних умовах, зокрема - у Правобережному Лісостепу.

Об'скти і методика дослідження. Об'єктом досліджень були насадження ялини європейської різного призначення, що ростуть у Правобережному Лісостепу України.

Предмет дослідження - сучасний стан, особливості розмноження, ріст i розвиток ялини європейської в умовах Правобережного Лісостепу України.

Мета дослідження - аналіз вікової структури та поширення ялини європейської у насадженнях Правобережного Лісостепу, удосконалення способів іiі розмноження та підвищення інтенсивності росту.

Вікову структуру деревостанів ялини європейської визначали за матеріалами державного обліку лісів станом на 01.01.2011 року. Для дослідження динаміки площ насаджень з іiі участю у Вінницькому ОУЛМГ використали повидільну (5963 виділи) базу даних лісовпорядкування 2007-2011 рр. Українського державного проектного лісовпорядного виробничого об'єднання «Укрдержліспроект».

Приживлюваність і ріст саджанців ялини у дослідних лісових культурах, а також лісівничотаксаційні характеристики деревостанів встановлювали за загальноприйнятими у лісівництві методиками (Hordienko, 1979). Життєвий стан рослин оцінювали за методикою О. М. Андрєєвої та ін. (Andreeva, Bakkal, Gorshkov et al., 2002).

Під час дослідження впливу препаратів на основі стимуляторів росту і розвитку рослин на схожість насіння ялини європейської цей показник визначали відповідно до вимог ГОСТу 13056.6-97.

Асептичні умови під час мікроклонального розмноження створювали за методами, загальноприйнятими у біотехнології (Kalinin, Sarnatskaya \& Polishchuk, 1980). Експлантати культивували на базовому безгормональному живильному середовищі за приписом Мурасіге-Скуга (Murashige \& Scoog, 1962) та МакКоуна-Ллойда (McCown \& Lloyd, 1981).

Вплив добрив на ріст саджанців ялини європейської вивчали за методикою Б. О. Доспєхова (Dospekhov, 1985). Озолення хвої для визначення вмісту макроелементів проводили за методом К. Гінзбурга. Загальний вміст сполук азоту оцінювали фотометричним методом з реактивом Несслера, фосфору - фотометрично за методом Деніже в модифікації А. Левицького, калію - полуменевим фотометром.

Для аналізу отриманих результатів застосовували методи математичної статистики (Shmidt, 1984) iз залученням пакета MS Excel.

Результати та обговорення. Для встановлення вікової структури ялинових деревостанів Правобережного Лісостепу аналізували насадження породи в межах п'яти областей, які територіально відносяться до вказаного регіону, а саме - Вінницької, Житомирської, Київської, Кіровоградської та Черкаської. За отриманими даними на території цих областей ялинові деревостани ростуть на площі 9303 га, серед яких переважають пристиглі віком 51-70 років (рис. 1$)$.

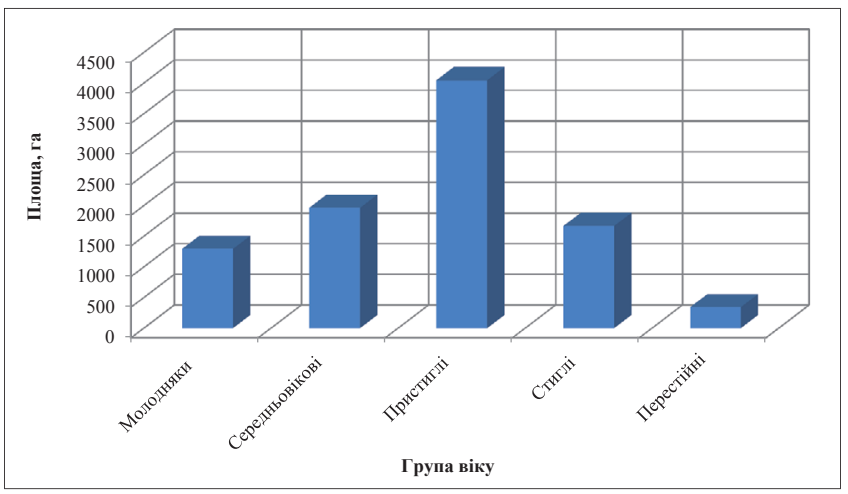

Рис. 1. Розподіл площі насаджень ялини європейської за групами віку

Порівняно невелика сумарна відносна площа молодняків $(13,9 \%)$ свідчить про зменшення обсягів створення штучних ялинових деревостанів у Правобережному Лісостепу впродовж останніх чотирьох десятиліть.

Негативним аспектом стійкості ялинників на цей час $є$ наявність значної площі, на якій ростуть стиглі та перестійні ялинові деревостани $(21,0 \%)$. 3 цього погляду особливу увагу варто приділити насадженням ялини європейської, вік яких перевищує 50 років, оскільки саме у цьому віці невчасне проведення необхідних лісогосподарських заходів призводить до всихання деревостанів (Debryniuk, 2011, Zhigunov, Semakova \& Shabunin, 2007, Fuchylo, 2011). 
Аналіз повидільної бази даних лісовпорядкування чистих і мішаних деревостанів Вінницького ОУЛМГ за 2007 і 2011 рр. дав змогу відобразити динаміку площ насаджень за участю ялини європейської та встановити їхні середні лісівничотаксаційні показники.

Так, за даними лісовпорядкування 2011 р., ялина росте у складі насаджень на площі 17134,2 га. При цьому значна частина ялинових деревостанів приурочена до лісових масивів ДП «Вінницьке ЛГ» (4144,7 га) та ДП «Іллінецьке ЛГ» (3316,7 га). Найменше насаджень за участю ялини виявлено у лісовому фонді ДП «Чечельницьке ЛГ» $(70,1$ га) та ДП «Ямпільське ЛГ» (27,2 га).

За період 2007-2011 рр. площа штучних насаджень за участю ялини європейської у Вінницькому ОУЛМГ збільшилася на 952,9 га (5,9\%), з яких 706,1 га (4,4\%) було створено у ДП «Вінницьке ЛГ».

Аналіз отриманих даних дає підставу зробити висновок про успішний ріст насаджень за участю ялини в регіоні досліджень, переважна більшість з яких характеризується I та I ${ }^{a}$ класами бонітету (рис. 2).

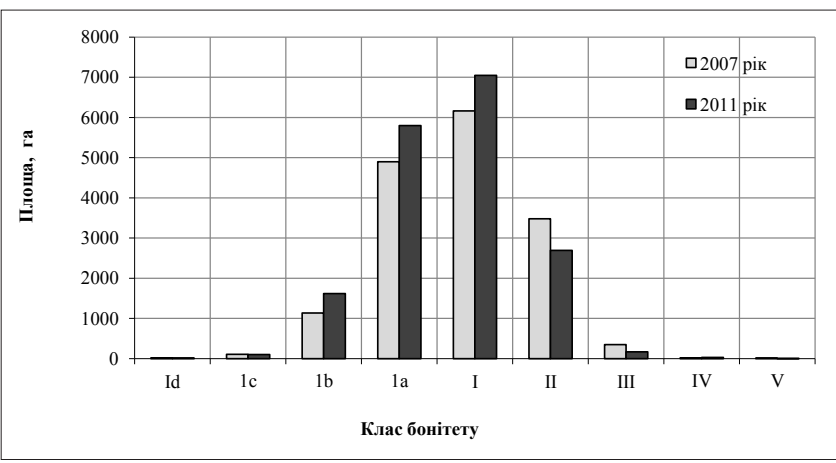

Рис. 2. Розподіл площі насаджень за участю ялини європейської за класами бонітету

Середній бонітет деревостанів за участю ялини станом на 2011 р. становив I ${ }^{\mathrm{a}}, 6$ або на $12 \%$ вище аналогічного показника 2007 p. ( $\left.\mathrm{I}^{\mathrm{a}}, 8\right)$, що свідчить про наявність у регіоні досліджень сприятливих лісорослинних умов для успішного росту деревостанів ялини навіть за нинішніх кліматичних змін. Підвищення середнього показника бонітету ялини європейської в насадженнях за несприятливої дії кліматичних чинників могло відбутися внаслідок попереднього відпаду біологічно нестійких, слабопродуктивних дерев.

Певним негативним аспектом є збільшення середнього віку деревостанів ялини європейської від 43,5 років у 2007 р. до 46,0 років у 2011 році. У віці понад 45 років в ялини поза межами природного ареалу спостерігається поява збудників кореневих гнилей, що призводить до послаблення iii біологічної стійкості (Debryniuk, 2011, Zhigunov, Semakova \& Shabunin, 2007, Fuchylo, 2011).

Незважаючи на збільшення площі насаджень за участю ялини у Вінницькій області, існує тенденція до зменшення іiї питомої ваги у складі насаджень загалом. Так, упродовж п’яти років площа чистих ялинових насаджень зменшилася на 14,0\% (від
675 га у 2007 р. до 592,4 га у 2011 р.), а середній показник частки участі ялини у складі мішаних насаджень зменшився на $25 \%$ (від $19 \%$ у 2007 р. до $14 \%$ у 2011 р.), що є загалом позитивною тенденці$є ю$, оскільки у мішаних насадженнях ялина відзначається вищою стійкістю до ураження збудниками хвороб і пошкодження шкідниками.

Для отримання високопродуктивних і біологічно стійких деревостанів ялини європейської важливе значення має створення насіннєво-селекційної бази в межах її штучного ареалу. В цьому напрямі важливе значення мають дослідження, здійснені на клоновій насінній плантації ялини, яка знаходиться у Веприківському лісництві ДП «Фастівське ЛГ» Київської області. Встановлено, що на плантації збереглося 75,8\% від загальної кількості висаджених щеплених клонів плюсових дерев ялини 3 усієї території України та Прибалтики. Найвищі показники збереженості, росту і продуктивності виявились у вегетативного потомства плюсових дерев ДП «Тростянецьке ЛГ» Сумської області та ДП «Старокостянтинівське ЛГ» Хмельницької області, що вказує на доцільність використання їхнього насіння для лісовідновних робіт у свіжих дібровах Правобережному Лісостепу. Найнижчими показниками продуктивності відзначалися найбільш віддалені - прибалтійські походження.

За необхідності отримання садивного матеріалу високопродуктивних чи декоративних форм ялини, корисні ознаки яких не передаються насінним шляхом, застосовують клональне мікророзмноження. У зв'язку з цим було вирішено вдосконалити метод мікроклонального розмноження рослин ялини європейської та їх адаптації до умов in vivo (Serediuk, Chornobrov, Klyuddenko \& Kolesnichenko, 2014).

Першим етапом клонального мікророзмноження $€$ стерилізація експлантів, від успішності проведення якого залежить успіх подальшого отримання рослин-регенерантів. Для стерилізації було залучено кілька стерилізуючих речовин з різною експозицією (табл. 1).

Отже, найвищий показник (понад $90 \%$ ) асептичних регенераційно здатних мікропагонів спостерігали за умови їх витримування в $1 \%$-му розчині $\mathrm{AgNO}_{3}$ упродовж 10 хв. 3 наступним перенесенням у $2,5 \%$-ий $\mathrm{NaClO}$ на 15 хвилин.

Управління процесами диференціації і морфогенезу в культурі ізольованих тканин і органів рослин in vitro відбувається шляхом внесення у живильне середовище екзогенних стимуляторів росту - ауксинів, цитокінінів, або гіберелінів. Результати їхнього впливу на регенераційну здатність відображено у табл. 2.

Встановлено, що у контролі та варіантах 1 i 2 живильних середовищ регенерація мікропагонів ялини європейської in vitro відбувалася шляхом активації росту наявних меристем експлантатів. Значну кількість рослин-регенерантів (коефіцієнт розмноження 1:9-1:23) одержано за умови використання безгормонального живильного середовища $1 / 2 \mathrm{MC}$. 
Ефективність стерилізації експлантатів рослин ялини свропейської

Таблиия 1

\begin{tabular}{cccccc}
\hline Варіант & $\begin{array}{c}\text { Стерилізуюча } \\
\text { речовина }\end{array}$ & $\begin{array}{c}\text { Концентрація, } \\
\%\end{array}$ & $\begin{array}{c}\text { Експозиція, } \\
\text { хв }\end{array}$ & $\begin{array}{c}\text { Кількість введених у культуру } \\
\text { in vitro експлантатів, шт. }\end{array}$ & $\begin{array}{c}\text { Ефективність } \\
\text { стерилізації, \% }\end{array}$ \\
\hline 1 & $\mathrm{NaClO}$ & 2,5 & 10 & 30 & $41,2 \pm 0,12$ \\
2 & $\mathrm{NaClO}$ & 2,5 & 20 & 30 & $23,1 \pm 0,25$ \\
3 & $\mathrm{AgNO}_{3}$ & 1,0 & 10 & 30 & $37,1 \pm 0,16$ \\
4 & $\mathrm{AgNO}_{3}$ & 1,0 & 20 & 30 & $57,4 \pm 0,07$ \\
5 & $\mathrm{AgNO}_{3}$ & 1,0 & 10 & 30 & $90,3 \pm 0,22$ \\
\hline
\end{tabular}

Морфометричні показники рослин-регенерантів ялини європейської на живильних

Таблиия 2 середовищах різного складу

\begin{tabular}{|c|c|c|c|c|c|c|}
\hline 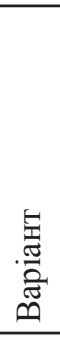 & Склад живильного середовища & 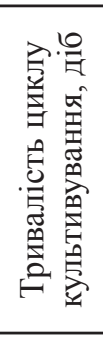 & 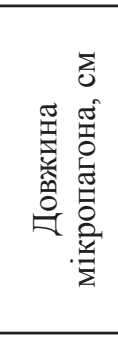 & 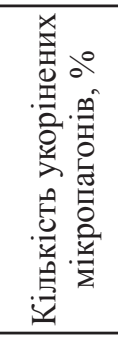 & 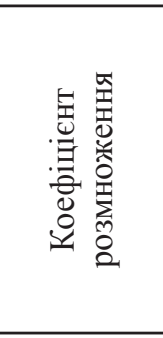 & 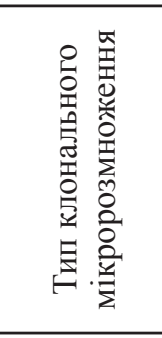 \\
\hline $\mathrm{K}^{1}$ & МС безгормональне & 30 & $2,5-3,0$ & $90-100$ & $1: 2-1: 4$ & a.p. M. e. ${ }^{2}$ \\
\hline 1 & 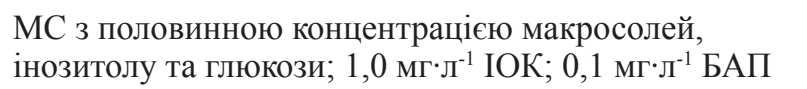 & 90 & $1,2-1,9$ & $90-100$ & $1: 5-1: 10$ & a. p. м. e. \\
\hline 2 & 1/2 МС безгормональне & 90 & $2,5-4,0$ & $90-100$ & 1:9-1:23 & a. p. м. е. \\
\hline \multirow[b]{2}{*}{3} & \multirow{2}{*}{ 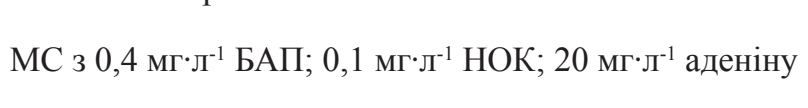 } & 60 & $1,2-2,0$ & 0 & $1: 5-1: 14$ & \multirow{2}{*}{ п. м. ${ }^{3}$} \\
\hline & & 90 & $2,9-4,0$ & 0 & $1: 20-1: 30$ & \\
\hline 4 & WPM з 1,0 мг $\cdot \pi^{-1}$ БАП; 2,0 мг $\cdot \pi^{-1}$ кінетину & 60 & $0,5-1,0$ & 0 & $1: 8-1: 10$ & п. м. \\
\hline
\end{tabular}

Примітка: 1 - контроль; 2 - активація росту меристем експланта; 3 - прямий морфогенез

Варто зазначити, що застосування варіантів 3 і 4 зумовило інтенсивне утворення мікропагонів, яке відбувалося шляхом прямого морфогенезу, за 60-90-добовий цикл культивування. Однак такі варіанти не стимулювали регенерацію кореневої системи. Показово, що культивування мікропагонів ялини європейської у варіанті 3 протягом 90 діб призводило до значного збільшення коефіцієнта розмноження мікропагонів (у 2,5 рази) та їх довжини (у два рази), порівняно з 60-добовим витримуванням (відмінності статистично значущі за 5 \%-го рівня значимості.

Важливим етапом мікроклонального розмноження $\epsilon$ адаптація рослин-регенерантів до умов закритого грунту. Упродовж адаптації рослин після культури in vitro важливе значення має забезпечення відповідних рівнів живлення рослин: мінерального, повітряного, водного та дотримання поступової зміни температури й вологості повітря навколишнього середовища. Дослідження підтвердили недоцільність використання для адаптації рослинрегенерантів ялини європейської однокомпонентного субстрату через надзвичайно низьку його ефективність (не перевищує 20\%). Значну кількість адаптованих рослин-регенерантів $(95 \%)$ отримали у варіанті з використанням соснової кори, деревного вугілля, торфу і сфагнового моху в пропорції $3: 2: 1: 1$ (рис. 3 ).

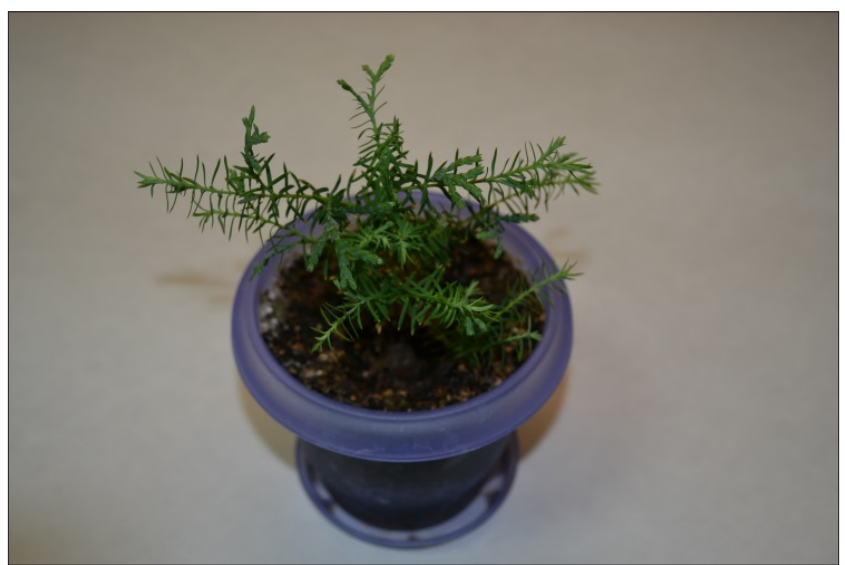

Рис. 3. Загальний вигляд адаптованої до умов закритого грунту рослини-регенеранта ялини європейської

Дослідження динаміки обсягів вирощування садивного матеріалу ялини європейської у лісогосподарських підприємствах Правобережного Лісостепу показали, що вирощування стандартних сіянців упродовж 2006-2011 рр. скоротилася майже у 2,5 
рази: від 4902,3 тис. шт. у 2006 р. до 2010,9 тис. шт. у 2011 p, а саджанців - учетверо (від 100,5 тис. шт. до 25,7 тис. шт.). Такі зміни вказують на зниження попиту на садивний матеріал ялини і необхідність розроблення заходів з підвищення стійкості цього деревного виду до умов навколишнього середовища в період кліматичних змін. Потрібні нові технологічні підходи до вирощування садивного матеріалу ялини як для лісового господарства, так і для потреб озеленення.

Важливою проблемою під час вирощування сіянців ялини $є$ забезпечення максимальної схожості iii насіння. Дослідження показали, що суттєвого підвищення показників лабораторної схожості можна досягти, використовуючи препарати на основі стимуляторів росту рослин. Для пророщування насіння нами використано розчини дев'яти найпоширеніших на українському ринку препаратів: гумат +7, циркон, гетероауксин, епін, ель, бурштинова кислота, корневін, корневіт і реаком у чотирьох різних концентраціях кожен. Як контроль використовували дистильовану воду. Результати показали, що найефективнішим для пророщування насіння ялини європейської виявився препарат епін у концентрації 0,3 мл· ${ }^{-1}$, під впливом якого відбулося підвищення відносного значення показника енергії проростання некондиційного насіння на $39,5 \%$, а схожості - на 30,7\% та кондиційного - відповідно на 18,1 та $17,9 \%$.

Важливу роль у проростанні насіння ялини в польових умовах відіграє субстрат, в якому його пророщують. Крім механічного складу і вологості, для проростання насіння дуже важливою $є$ кислотність субстрату. Вивчення цього питання особливо актуальне для вирощування садивного матеріалу ялини європейської із закритою кореневою системою. Дослідження впливу субстратів з різними показниками кислотності (варіант 1 - $\mathrm{pH} 4,0 ; 2$ - $\mathrm{pH} 4,6 ; 3$ - $\mathrm{pH}$ 6,0; 4 - $\mathrm{pH} 6,2 ; 5-\mathrm{pH} 6,9$; контроль - мікоризований грунт з-під намету ялинового насадження - $\mathrm{pH} 6,2$ ) показали, що найвищими показниками енергії проростання, схожості насіння і середньої висоти сіянців відзначаються субстрати з $\mathrm{pH}$ 6,2 (табл. 3).

На кисліших субстратах (варіанти 1, 2, 3) і субстраті $з$ рH 6,9 (варіант 5) схожість насіння та висота сіянців ялини були нижчими. Найбільш негативний вплив на схожість насіння і ріст сіянців виявив найкисліший субстрат (pH 4,0), в якому висота сіянців на 17,9\% була меншою порівняно 3 контролем, а схожість насіння становила лише $56,7 \%$. Отриманню високих показників схожості насіння i росту сходів на контролі сприяла наявність у субстраті мікоризи, характерної для грунтів під ялиновими насадженнями.

Таблиия 3

\section{Енергія проростання, схожість насіння та висота сіянців ялини свропейської на субстратах} 3 різною кислотністю

\begin{tabular}{ccccc}
\hline $\begin{array}{c}\text { Варіант } \\
\text { досліду }\end{array}$ & Показник рН & $\begin{array}{c}\text { Енергія } \\
\text { проростання, \% }\end{array}$ & Схожість, $\%$ & $\begin{array}{c}\text { Середня висота сіянців через 30 діб } \\
\text { 3 моменту сівби, мм }\end{array}$ \\
\hline 1 & 4,0 & 41,0 & 56,7 & $21,9 \pm 1,01$ \\
2 & 4,6 & 62,9 & 69,4 & $23,1 \pm 0,91$ \\
3 & 6,0 & 66,2 & 75,7 & $24,2 \pm 1,16$ \\
4 & 6,2 & 68,6 & 83,3 & $27,4 \pm 1,04$ \\
5 & 6,9 & 52,4 & 64,3 & $22,1 \pm 1,07$ \\
Контроль & 6,2 & 81,0 & 83,3 & $26,7 \pm 1,13$ \\
\hline
\end{tabular}

У процесі вирощування штучних насаджень за участю ялини європейської важливе значення має технологія створення, яка забезпечувала б високий показник приживлюваності, біологічну стійкість та якнайкоротші терміни змикання крон у лісових культурах. Одним із елементів ефективної технології лісовідновлення насаджень ялини може бути використання ростових речовин для стимуляції коренеутворення і пришвидшення ростових процесів загалом.

3 метою вивчення впливу стимуляторів росту на приживлюваність ялини у лісових культурах нами навесні 2010 р. було висаджено трирічні сіянці ялини європейської, кореневі системи яких попередньо намочували у розчинах циркону, вимпелу, корневіну, елю та екопланту. Як контроль використовували дистильовану воду. Результати дослідження приживлюваності і росту рослин протягом вегетаційних періодів 2010 і 2011 рр. представлені в табл. 4 та на рис. 4.
Отже, всі застосовані стимулятори росту спричинили позитивний вплив на приживлюваність $\mathrm{i}$ ріст саджанців. Після першого вегетаційного періоду найвищу приживлюваність встановлено у сіянців, кореневу систему яких було намочено у роз-

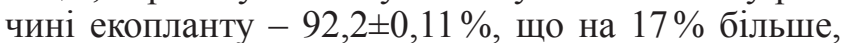
ніж приживлюваність рослин на контролі.

Середній річний приріст таких сіянців за висотою становив $3,4 \pm 0,28 \mathrm{~cm}$, що на $73 \%$ перевищує показники контролю. У випадку застосування корневіну приживлюваність рослин становила $90,3 \pm 0,59 \%$ (на $14 \%$ більше від контролю), а


від контролю). Застосування циркону підвищило приживлюваність сіянців на $13 \%$, а приріст за висотою - на $41 \%$. У варіанті з використанням вимпелу приживлюваність була вищою відносно контролю лише на $8 \%$, але середній річний приріст - на $43 \%$. Отримані результати досліджень 
після завершення вегетаційного періоду першого року у випадку застосування препарату «Ель» показали наявність перевищення контролю за приживлюваністю на $11 \%$, а за середнім річним приростом - на $13 \%$.

Після завершення другого вегетаційного періоду найбільше рослин збереглось у варіанті з використанням екопланту - на $37 \%$ більше, ніж на контр- олі. Також у цьому варіанті встановлено значний середній річний приріст саджанців за висотою (на $31 \%$ вищий, ніж на контролі). Найвищий приріст за висотою виявився у варіанті з використанням корневіну - на 43 \% більше, ніж на контролі. Приживлюваність сіянців тут була більшою від контролю на $32 \%$.

\section{Приживлюваність ялини свропейськоїу лісових культурах за обробки коренів саджанців} стимуляторами росту

\begin{tabular}{|c|c|c|c|}
\hline \multirow{2}{*}{$\begin{array}{l}\text { Номер } \\
\text { варіанта }\end{array}$} & \multirow{2}{*}{ Препарат } & \multicolumn{2}{|c|}{ Приживлюваність за роками, \% } \\
\hline & & 2010 & 2011 \\
\hline 1 & «Циркон» (суміш гідроксикоричних кислот) & $88,8 \pm 0,35$ & $77,1 \pm 0,42$ \\
\hline 2 & 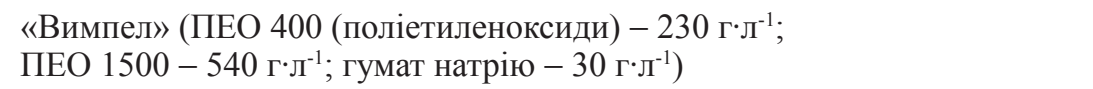 & $85,1 \pm 0,38$ & $82,0 \pm 0,84$ \\
\hline 3 & «Корневін» (3-індолілмасляна кислота -5 г·кг-1) & $90,3 \pm 0,59$ & $86,1 \pm 0,65$ \\
\hline 4 & «Ель» (арахідонова кислота - 1,2 г·л"-1) & $87,2 \pm 0,33$ & $84,6 \pm 0,74$ \\
\hline 5 & $\begin{array}{l}\text { «Екоплант» }\left(\mathrm{P}_{2} \mathrm{O}_{5}-7,66 \% ; \mathrm{K}_{2} \mathrm{O}-49,29 \% ; \mathrm{MgO}-10,03 \% ; \mathrm{CaO}-12,26 \% \text {; }\right. \\
\mathrm{Fe}-0,134 \% ; \mathrm{B}-0,1 \% ; \mathrm{Zn}-0,09 \% ; \mathrm{Cu}-0,024 \% ; \mathrm{Mn}-0,015 \% ; \\
\mathrm{Cr}-0,00063 \% ; \mathrm{Mo}-0,00015 \% ; \mathrm{Co}-0,000037 \% \text { відповідно })\end{array}$ & $92,2 \pm 0,11$ & $88,8 \pm 0,45$ \\
\hline & Контроль & $78,9 \pm 0,21$ & $64,9 \pm 0,69$ \\
\hline
\end{tabular}

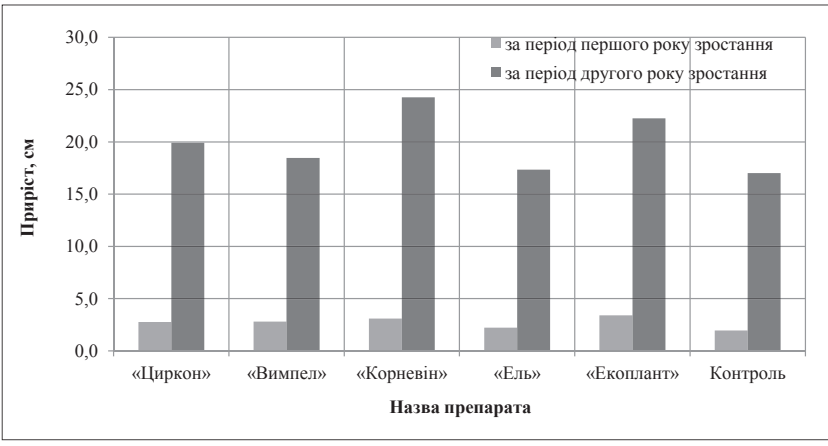

Рис. 4. Приріст ялини європейської за висотою у лісових культурах, створених з використанням стимуляторів росту рослин

Отже, для підвищення успішності створення лісових культур ялини трирічними сіянцями доцільно перед садінням кореневі системи сіянців замочувати на 16 год у водних розчинах екопланту і корневіну.

Суттєвого підвищення інтенсивності росту і поліпшення фізіологічного стану висаджених на лісокультурну площу саджанців можна досягти внесенням у грунт мінеральних і органічних добрив. Спеціальний дослід з вивчення цього питання проводили на території розсадника Ботанічного саду НУБіП України впродовж 2011-2012 років.

Досліджували дію підживлення на ріст трирічних саджанців ялини європейської двох комплексних мінеральних добрив: «Green field» (N - 12\%; $\left.\mathrm{P}_{2} \mathrm{O}_{5}-12 \% ; \mathrm{K}_{2} \mathrm{O}-33 \%\right) 3$ дозою внесення $40 \Gamma^{\cdot} \mathrm{M}^{-2}$ $\mathrm{i}$ «Новоферт універсал» (N $-20 \% ; \mathrm{NH}_{4}-4 \%$; $\mathrm{NH}_{2}-10 \% ; \mathrm{NO}_{3}-6 \% ; \mathrm{P}_{2} \mathrm{O}_{5}-20 \% ; \mathrm{K}_{2} \mathrm{O}-20 \% ; \mathrm{MgO}-$ $1 \% ; \mathrm{Fe}-0,0045 \% ; \mathrm{Cu}-0,0045 \% ; \mathrm{Mn}-0,0225 \%$; $\mathrm{Zn}-0,011 \%$; Мо - 0,001\%; В - 0,0135\%) - $40 \Gamma^{\cdot} \mathrm{M}^{-2}$; органічного добрива «Біодобриво для хвойних рослин» $\left(\mathrm{N}-3,6 \% ; \mathrm{P}_{2} \mathrm{O}_{5}-2,5 \% ; \mathrm{K}_{2} \mathrm{O}-3,2 \%\right.$; $\mathrm{Zn}-0,004 \% ; \mathrm{B}-0,006 \% ; \mathrm{Cu}-0,002 \% ; \mathrm{Mn}-0,004 \%$; $\mathrm{Fe}-0,006 \%$; Mo - 0,0002\%) - 15 мл м $^{-2}$ та однокомпонентного мінерального добрива - аміачної селітри $\left(\mathrm{NH}_{4} \mathrm{NO}_{3}-34 \%\right)-40 \Gamma^{\cdot} \mathrm{M}^{-2}$.

Вносили добрива упродовж двох вегетаційних періодів (2011-2012 рр.) 3 третьої декади квітня до другої декади серпня шляхом кореневого підживлення один раз на місяць. Після підживлення рослини інтенсивно поливали водою з розрахунку 25 л води на 1 м $^{2}$. Висоту рослин вимірювали тричі впродовж вегетаційного періоду (у третій декаді травня, серпня і жовтня) протягом двох років.

Встановлено, що після завершення другого вегетаційного періоду середні показники річних приростів удобрених рослин за дворічний період були вищими, ніж на контролі - від 4,3 см (14\%) до11,2 см (56\%). Середній показник приросту за висотою у саджанців, яких підживлювали комплексним мінеральним добривом «Green field», був найвищим і становив $31,3 \pm 0,52$ см, що на $56 \%$ вище, ніж на контролі.

Отримання високих показників приросту саджанців упродовж двох років росту забезпечило також кореневе підживлення органічним добривом «Біодобриво для хвойних»: показник середнього приросту удобрених ним рослин на $32 \%$ вищий від контролю. Встановлено, що мінеральні елементи спричиняють максимальну стимулюючу дію на ростові процеси саджанців на початку першого вегетаційного періоду. Ефективному росту саджанців сприяли також мінеральні добрива «Новоферт універсал» та аміачна селітра: середні показники приростів за два роки їх застосування складали,

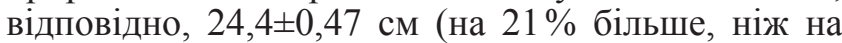


контролі) та 24,6 0,78 см (на $22 \%$ більше, ніж на контролі).

Внесення добрив суттєво вплинуло також на вміст макроелементів у хвої саджанців. Найбільш збалансованим він виявився у хвої рослин, підживлених мінеральним добривом «Green field» (рис. 5).

Інтенсивне підживлення саджанців ялини аміачною селітрою спричинило інтенсифікацію росту пагонів у кінці вегетаційного періоду на $133 \%$ порівняно 3 контролем і нагромадження хвоєю значної кількості азоту, що негативно вплинуло на їх здерев'яніння.

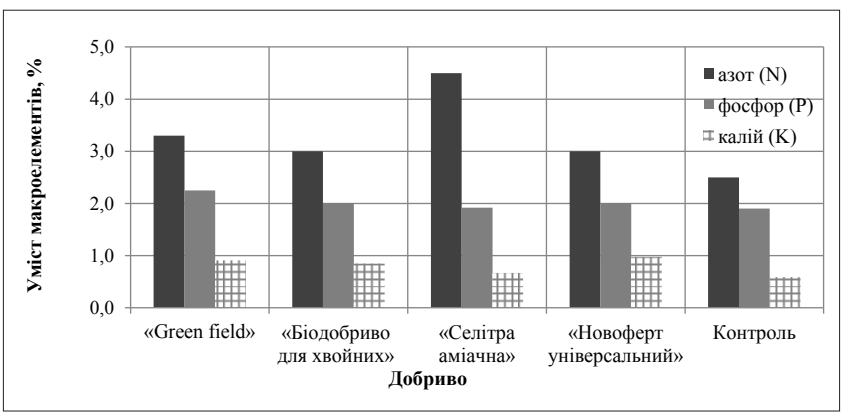

Рис. 5. Вміст макроелементів у хвої ялини європейської за дії мінерального живлення

Перспективним напрямом вирощування садивного матеріалу ялини $є$ використання контейнерної культури. За результатами досліджень основою успішного вирощування садивного матеріалу ялини європейської в контейнерах є правильний добір субстрату і оптимальної періодичності переконтейнерування рослин. Встановлено, що найсприятливішим для вирощування ялини є слабокислий субстрат (рН 6,2), а схема вирощування саджанців передбачає висів насінин і вирощування однорічних сіянців у мультиплатах (ємкість комірок 46 мл), наступні два роки - у контейнерах ємкістю 0,5 л та ще три роки у трилітрових контейнерах. На цей час середня висота саджанців становить близько 50 см. Після цього саджанці, за необхідності, можна висаджувати у відкритий грунт або пересаджувати у п'ятилітрові контейнери для подальшого дорощування.

Висновки. Ялина європейська у насадженнях Правобережного Лісостепу характеризується високими лісівничо-таксаційними показниками. Впродовж п'ятирічного періоду (2007-2011рр.) відбулося збільшення середнього діаметра їі насаджень на $9,1 \%$ і середньої висоти на $8,8 \%$.

Найвищою інтенсивністю росту ( $\mathrm{I}^{\mathrm{b}}$ клас бонітету) на лісонасінній плантаціії ялини європейської (Фастівський лісгосп, свіжа діброва, $D_{2}$ ) відзначаються вегетативні потомства плюсових дерев 3 Хмельницької та Сумської областей. Найменшими ці показники виявилися у клонів прибалтійського походження.

Результати дослідження дії низки стимуляторів росту рослин на схожість насіння ялини європейської показали, що найвищу ефективність мав препарат «Епін» у концентрації 0,3 мл ग $^{-1}$. Обробка ним некондиційного насіння сприяла підвищенню показника енергії проростання на 39,5\%, схожості - на 30,7\% та кондиційного - на 18,1 і 17,9\% відповідно.

Почергове витримування експлантатів ялини європейської у $1 \%$-му розчині $\mathrm{AgNO}_{3}$ та $2,5 \%$-му $\mathrm{NaClO}$ забезпечило отримання значної кількості асептичних здатних до регенерації мікропагонів (90\%). Найбільшу кількість рослин-регенерантів одержано за умови використання безгормонального живильного середовища 3 половинною концентрацією Мурасіге-Скуга. Високу ефективність адаптації отриманих рослин-регенерантів до умов закритого середовища $(95 \%)$ забезпечив субстрат, який містить соснову кору, деревне вугілля, торф і сфагновий мох у пропорції 3:2:1:1.

Обробка кореневих систем сіянців ялини європейської перед садінням препаратами корневін або екоплант забезпечує їх високу приживлюваність (на 23\% більше порівняно 3 контролем) та значну інтенсивність росту (в 1,5 рази вищу, ніж на контролі) після двох років росту.

Використання мінерального добрива «Green field» $\left(\mathrm{N}-12 \% ; \mathrm{P}_{2} \mathrm{O}_{5}-12 \% ; \mathrm{K}_{2} \mathrm{O}-33 \%\right)$ для кореневого підживлення саджанців ялини європейської сприяло підвищенню інтенсивності їх росту впродовж дворічного періоду (на $55 \%$ порівняно 3 контролем).

Технологія вирощування садивного матеріалу ялини європейської із закритою кореневою системою передбачає використання слабокислих субстратів (pH 6,2), вирощування однорічних сіянців у мультиплатах (ємкість комірок 46 мл), наступні два роки - у контейнерах ємкістю 0,5 л і три роки - у трилітрових контейнерах.

\section{Бібліографічні посилання}

Andreeva, E. N., Bakkal, I. Yu., Gorshkov, V. V. et al. (2002). Methods of studying of forest communities. Moscow: SRI of Chemistry of SPBSU (in Russian).

Bondar, A. O., \& Hordienko, M. I. (2006). Formation of forest plantations in the dubravas of Podillya. Kyiv: Harvest (in Ukrainian).

Debryniuk, Yu. M. (2011). Dying of spruce forests: causes and consequences. Scientific Bulletin of the National Forestry University of Ukraine, 21 (16), 3238 (in Ukrainian).

Debryniuk, Yu. M. (2003). Influence of mixing schemes on the growth and productivity of oak and fir in forest crops of the Western Forest-steppe. Scientific Bulletin of the Ukrainian State Forestry University, 13.4, 37 46 (in Ukrainian).

Debryniuk, Yu. M., \& Dumansky O. I. (2010). Growth and productivity modeling of Picea abies [L.] Karst. plantations as forest plantations prototype in the Western region of Ukraine. Proceedings of the Forestry Academy of Sciences of Ukraine, 8, 83-90 (in Ukrainian)

Dospekhov, B. A. (1985). Methodology of field studies. Moscow: Agropromizdat (in Russian). 
Fuchylo, Ya. D. (2011). Plantation Forestry: Theory, Practice, Perspectives. Kyiv: Logos (in Ukrainian).

Grodzki, W. (2007). Spatially-temporal patterns of the Norway spruce decline in the Beskid Śląski and Zywiecki (Western Carpathians) in southern Poland. Journal of Forest Science, 53 (Special Issue), 38-44.

Holubets, M. A. (1958). The use of Norway spruce for improving forest productivity on the plain part of the western regions of the Ukrainian SSR. The Harold of agricultural Science, 4, 51-56 (in Ukrainian).

Hordienko, I. I. (1953). Fast-growing spruce cultures. Proceedings of the Institute of Forestry, 5, 147-156 (in Ukrainian).

Hordienko, I .I. (1967). Mutual influence of spruce and oak. Kyiv: Scientific thought (in Ukrainian).

Hordienko, M.I. (1979). Methodological guidelines for the study and investigation of forest crops. Kyiv: Ukrainian Agricultural Academy (in Russian).

Kalinin, F. L., Sarnatskaya, V. V., \& Polishchuk, V. E. (1980). Methods of tissue culture in plant physiology and biochemistry. Kyiv: Scientific thought (in Russian).

Kozlovsky, M. P., Kramarets,V. O., \& Tselen, Y. P. (2013). Modern tendencies and causes of Norway spruce forests drying in the Beskydy region and ways to improve their sanitary condition. Scientific fundamentals of biotic diversity preservation, 4 (11), 167-180 (in Ukrainian).

Leontovyc, R., \& Kunca, A. (2006). The role of fungal pathogens in the premature decay of Norway spruce stands in Slovakia. Current problems of forest protection in spruce stands under conversion. Forest Research Institute, 79-84.

McCown, B. H., \& Lloyd, G. B. (1981). Woody plant medium (WP 14) - a mineral nutrient formulation for microculture of woody plant species. Ibid. 16, 453.

Murashige ,T., \& Scoog, F. (1962). A revised medium for rapid, growth and bioassays with tobacco tissue cultures. Physiol. Plant., 15, (3), 473.

Serediuk, O. O., Chornobrov, O. Yu., Klyuddenko, A.A., \&Kolesnichenko, O. V. (2014). Optimization of traditional and newest research methods of propagation of Norway spruce (Picea abies (L.) H. Karst.) in vivo and in vitro conditions. Scientific Bulletin of the National University of Life and Environmental Sciences of Ukraine, 198 (1), 113-122 (in Ukrainian).

Shmidt, V. M. (1984) Mathematical Methods in Botany. Leningrad: Publishing house of Leningrad University (in Russian).

Vasilevsky, O. H. (2009). Analysis of the condition and productivity of oak-spruce forests of different ages of Podillya. Forestry and forest melioration, 115, 106110 (in Ukrainian).

Zhigunov, A. V., Semakova, T. A., \& Shabunin, D. A. (2007). Mass drying of forests in the North-West of Russia. Retrieved from http: // http://resources. krc.karelia.ru/krc/doc/publ2007/forest_biology research_042-52.pdf_(in Russian).

\section{Ель европейская в Правобережной Лесостепи Украины: перспективы использования и усовершенствование способов размножения}

\author{
Я.Д. Фучило', А. А. Середюк²
}

Сегодня в Украине и за ее пределами серьезной проблемой стало усыхание ели европейской в искусственных насаждениях разного целевого назначения. Учитывая важное хозяйственное и социальное значение ели, значительную актуальность приобретают исследования ее состояния, роста и развития в различных почвенно-климатических условиях.

Целью проведенных исследований была оценка состояния ели европейской в насаждениях Правобережной Лесостепи, совершенствование способов ее размножения и поиск путей повышения производительности и устойчивости.

Анализ возрастной структуры еловых древостоев Правобережной Лесостепи показал, что приспевающие древостои (возраст 51-70 лет) занимают 43,5\% от общей площади еловых насаждений. Спелые и перестойные насаждения составляют более $21 \%$, а молодняки - 13,9\%.

В целом насаждения ели европейской характеризуется высокими лесоводственно-таксационными показателями. Значительное количество древостоев имеет средний диаметр больше 30 см и среднюю высоту более 22 м. Участие ели в составе искусственных насаждений региона исследований со временем уменьшается.

Исследования клоновой лесосеменной плантации ели европейской (Фастовский лесхоз, свежая дубрава, $D_{2}$ ) свидетельствуют, что самыми высокими показателями роста ( ${ }^{\mathrm{b}}$ класс бонитета) в этих условиях отличались клоны плюсовых деревьев из Хмельницкой и Сумской областей. Наименьшие показатели оказались у клонов прибалтийского происхождения.

Установлено, что за счет использования стимуляторов роста и развития растений возможно повышение всхожести семян ели европейской на $30,7 \%$ и приживаемости в лесных культурах на $36,8 \%$.

Определены оптимальные условия для эффективного клонального микроразмножения растений ели европейской. Получение $90 \%$ асептических

Фучило Ярослав Дмитриевич - действительный член Лесной академии наук Украины, доктор сельскохозяйственных наук, профессор, главный научный сотрудник. Институт биоэнергетических культур и сахарной свеклы НААН Украины, ул. Клиническая, 25, г. Киев, 03141, Украина. Тел. +38-067-60591-41. E-mail: fuchylo_yar@ukr.net

Середюк Александр Алексеевич - кандидат сельскохозяйственных наук, заместитель директора ботанического сада. Национальный університет биоресурсов и природопользования Украины, ул. Героев Обороны, 15, г. Киев, 03041,Украина. Тел. +38-096-233-51-37. E-mail: serediyk-olexandr@ukr.net 
способных к регенерации микропобегов обеспечивает поочередное выдерживание эксплантатов в $1 \%$-ном растворе $\mathrm{AgNO}_{3}$ и 2,5\%-ном $\mathrm{NaClO}$. Использование безгормональной питательной среды с половинной концентрацией Мурасиге-Скуга способствует получению значительного количества растений-регенерантов. Высокую эффективность адаптации $(95 \%)$ полученных растений к условиям in vivo обеспечивает субстрат, содержащий сосновую кору, древесный уголь, торф и сфагновый мох в пропорции $3: 2: 1: 1$.

При исследовании действия удобрений на рост ели было установлено, что наивысшей эффективностью отличалось комплексное минеральное удобрение, содержащее: $\mathrm{N}-12 \%, \mathrm{P}_{2} \mathrm{O}_{5}-12 \%$ и $\mathrm{K}_{2} \mathrm{O}-$ $33 \%$.

Подобраны эффективные субстраты для выращивания посадочного материала ели европейской с закрытой корневой системой. Разработана технология выращивания ее посадочного материала в контейнерной культуре.

Ключевые слова: Picea abies (L.) Karst.; древостой; семена; саженцы; стимуляторы роста и развития растений; контейнерная культура; минеральные удобрения; клональное микроразмножение.

\section{Norway spruce in the Right Bank Forest-Steppe of Ukraine: perspectives of use and improvement of reproduction methods}

\author{
Ya. Fuchylo', O. Serediuk ${ }^{2}$
}

Today, in Ukraine and abroad, the drying up of Norway spruce trees in forest plantations of different purpose has become a serious problem. Considering the important economic and social significance of spruce, studies of its condition, growth and development

Yaroslav Fuchylo - full member of the Forestry Academy of Sciences of Ukraine, Doctor of Agricultural Sciences, Professor, Chief Scientist. Institute of Bioenergy Crops and Sugar Beet, National Academy of Agrarian Sciences of Ukraine, Clinical str., 25, Kyiv, 03141, Ukraine. Tel. +38-067-605-91-41. E-mail: fuchylo_yar@ ukr.net

Olexandr Serediuk - Ph.D. in Agricultural Sciences, Deputy Director of the Botanical Garden. National University of Life and Environmental Sciences of Ukraine. Heroyiv Oborony st., 15, Kyiv, 03041,Ukraine. Tel.: +38-096-233-51-37. E-mail: serediykolexandr@ukr.net in various soil and climatic conditions acquire considerable relevance. The aim of the conducted studies was to assess the condition of Norway spruce in plantations of the Right-bank Forest-Steppe zone to improve the methods of its reproduction and to find ways to increase productivity and sustainability.

Analysis of the age structure of spruce stands of the Right-bank Forest-Steppe showed that the growing stands (age $51-70$ years) occupy $43.5 \%$ of the total area of spruce stands. Ripe and over-mature stands account for more than $21 \%$, and young tree stands $13.9 \%$. In general, the plantations of Norway spruce are characterized by high silvicultural and biometric indicators. A significant number of stands have an average diameter of more than $30 \mathrm{~cm}$ and an average height of more than $22 \mathrm{~m}$. The share of spruce in the composition of plantations in the study region decreases with time.

Studies of the clonal forest seed plantation of in vitro Norway spruce (Fastiv Forestry, fresh dibrova condition, $D_{2}$ ) indicate that clones of plus trees from Khmelnitsky and Sumy regions differed in the highest growth indices ( $\mathrm{I}^{\mathrm{b}}$ class of bonitet). The smallest of these indicators were found in clones of Baltic origin.

It is established that due to the use of growth substances, it is possible to increase the germination of Picea abies seeds by $30.7 \%$ and the survival rate of forest crops by $36.8 \%$.

Optimal conditions for effective clonal micropropagation of Norway spruce plants have been determined. It was found that obtaining $90 \%$ of aseptic regeneration-capable micro sprouts ensures alternate exposure of the explants in a $1 \%$ solution of $\mathrm{AgNO}_{3}$ and $2.5 \% \mathrm{NaClO}$. The use of a hormone-free medium with half the concentration of Murashige-Skoog promotes the production of a significant number of regenerative plants. High adaptation efficiency $(95 \%)$ of the obtained plants to in vivo conditions is provided by a substrate containing pine bark, charcoal, peat and sphagnum moss $(3: 2: 1: 1)$.

When studying the effect of fertilizers on the growth of spruce, it was found that a complex mineral fertilizer containing: $\mathrm{N}-12 \%, \mathrm{P}_{2} \mathrm{O}_{5}-12 \%$ and $\mathrm{K}_{2} \mathrm{O}-$ $33 \%$ was the most effective. Efficient substrates for cultivation of planting stock of Norway spruce with a closed root system were selected. The technology of cultivation of its planting material in container culture is developed.

Key words: Picea abies (L.) Karst.; tree stand; seeds; seedlings; growth substance; container culture; mineral fertilizers; clonal micropropagation. 